San Jose State University

From the SelectedWorks of Sen Chiao

February, 2013

Leeside Boundary Layer Confluence and Afternoon Thunderstorms over Mayaguez, Puerto Rico

Mark R. Jury, University of Puerto Rico, Mayaguez

Sen Chiao, San Jose State University 


\title{
Leeside Boundary Layer Confluence and Afternoon Thunderstorms over Mayaguez, Puerto Rico
}

\author{
MARK R. JURY \\ Physics Department, University of Puerto Rico, Mayaguez, Puerto Rico, and University of Zululand, \\ KwaDlangezwa, South Africa \\ SEN CHIAO \\ Department of Meteorology and Climate Science, San José State University, San José, California
}

(Manuscript received 22 April 2011, in final form 10 August 2012)

\begin{abstract}
The midsummer boundary layer (BL) circulation and afternoon thunderstorm convection on the lee side of Puerto Rico is studied using observations and high-resolution models. Satellite infrared data help to identify cases on 5 and 14 June 2010 when midday surface temperatures show a $2^{\circ} \mathrm{C}$ gradient between land and sea and afternoon cloud-top temperatures $<-60^{\circ} \mathrm{C}$. Acoustic sounder profiles are analyzed for climatology, wind shear, turbulence, and diurnal cycles in the 40-300-m layer. Weather Research and Forecasting (WRF) model simulations indicate that sea-breeze flow is entrained into convective cells near Mayaguez, Puerto Rico. The simulated BL wind shear is too weak $\left(0.5 \times 10^{-2} \mathrm{~s}^{-1}\right)$ in comparison with the acoustic sounder $\left(2 \times 10^{-2} \mathrm{~s}^{-1}\right)$. Model 900 -hPa winds are southeasterly and spread simulated convection too far north in comparison with radar. The pattern of near-surface winds in the island wake triggers afternoon thunderstorms near Mayaguez. A feature of the confluent circulation around Puerto Rico is opposing shear zones on the leeward corners of the island and a sea breeze of $5 \mathrm{~m} \mathrm{~s}^{-1}$ over the west coast during midday.
\end{abstract}

\section{Introduction}

Atmospheric boundary layer (BL) confluence often triggers moist convection along shear lines associated with frictional drag and surface heat fluxes (Wilson and Schreiber 1986). Over the Florida peninsula dual sea-breeze circulations generate convergence and afternoon thunderstorms (Cooper et al. 1982; Blanchard and López 1985; Wakimoto and Atkins 1994; Kingsmill 1995). Deep summer convection over the western Pacific Ocean islands was related to confluent circulations under daytime heating, with large-scale easterly flow opposed by low-level westerly sea breezes (Liu and Moncrieff 1996; Carbone et al. 2000; Keenan et al. 2000; Nordeen et al. 2001). Smith et al. (1997) have studied the convective streamers that extend downstream

Corresponding author address: Sen Chiao, Dept. of Meteorology and Climate Science, San José State University, San José, CA 95192.

E-mail: sen.chiao@sjsu.edu from subtropical islands. Narrow wakes under strong trade winds were compared with broad wakes under lighter flow (Schar and Smith 1993a,b; Grubišić et al. 1995). An island's frictional drag and daytime heating can produce confluent shear zones that organize the convection (Etling 1989; Jury et al. 2009, hereinafter J09). Observation and modeling around the Hawaiian Islands have revealed a long wind shadow (Smith and Grubišić 1993; Burk et al. 2003; Carlis et al. 2010; Nguyen et al. 2010) and cloud bands along the leading edges (Smolarkiewicz et al. 1988; Rasmussen et al. 1989) with Froude number of less than 0.5. An understanding of these processes can aid short-range local weather forecasts.

Puerto Rico is an island in the central Caribbean, $18.1^{\circ}-18.4^{\circ} \mathrm{N}, 67.5^{\circ}-65.5^{\circ} \mathrm{W}(70 \mathrm{~km} \times 200 \mathrm{~km})$, with a zonal mountain ridge of greater than $600 \mathrm{~m}$ in elevation (Fig. 1a). The land surface vegetation fraction is greater than 0.7 except in late winter and the island is bordered by the warm Caribbean Sea on its southern flank where surface temperatures exceed $28^{\circ} \mathrm{C}$ in summer. Trade winds prevail $85 \%$ of the time and there are few islands 

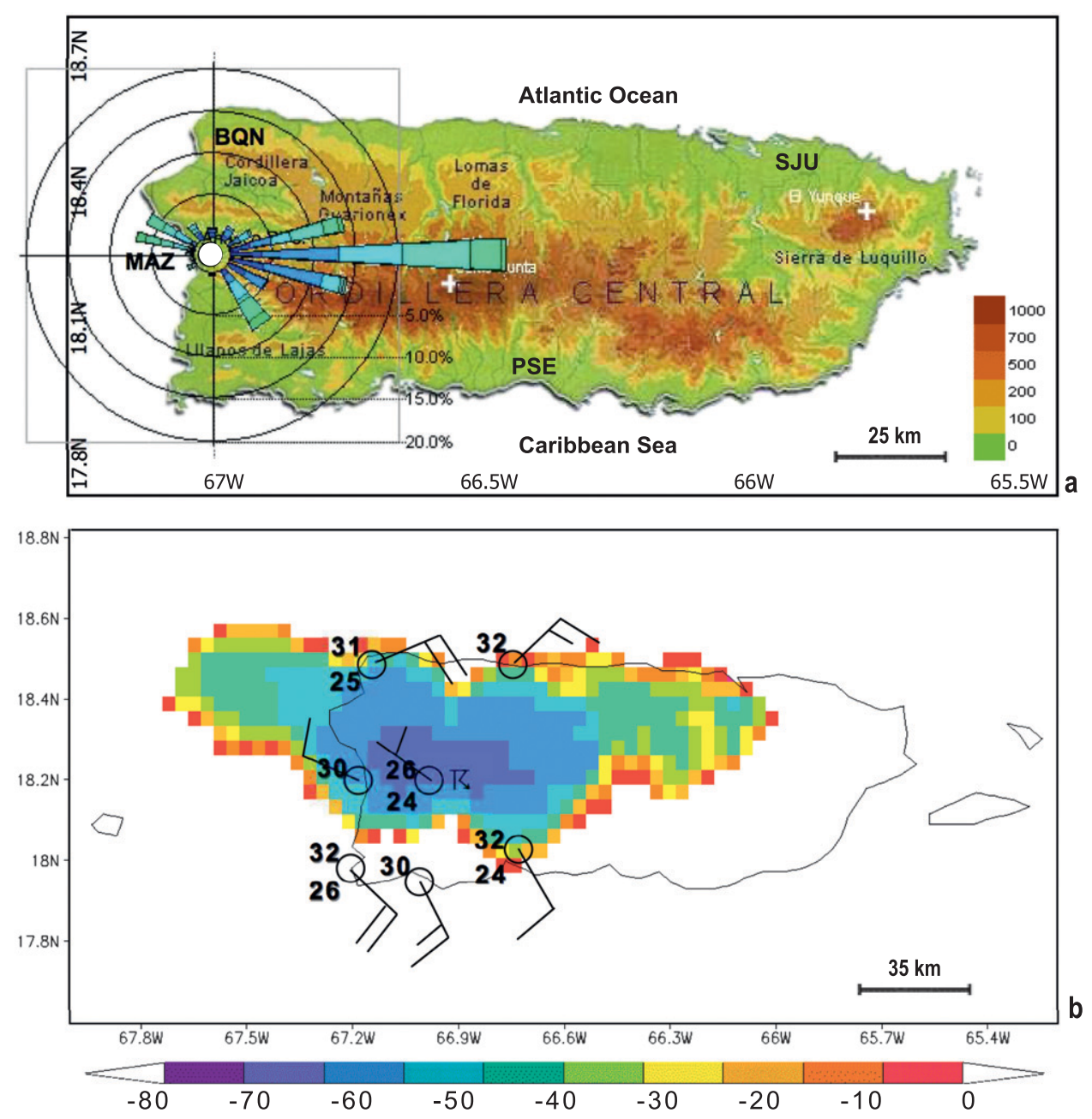

FIG. 1. (a) Topographic map of Puerto Rico (m), airport stations, and June 2010 100-m wind rose from the acoustic sounder. (b) Geostationary Operational Environmental Satellite infrared temperatures at 1400 LST 14 Jun 2010 and station data plots. Map scales vary.

upwind. Puerto Rico's topography generates confluent BL circulations that organize convective clouds in bands during the afternoon (Malkus 1955; Pearce et al. 1956). In steady easterly flow, a simple model exhibited a trapped leeside wave near Mayaguez, Puerto Rico (Bennett et al. 1998), and northeasterly (southeasterly) trade winds along the north (south) coast during midday. The confluent convection over the western interior of Puerto Rico is so frequent that mean annual rainfall doubles in comparison with that found on the upstream coast. Our study is motivated by the need for more accurate shortrange wind and streamflow forecasts. We make use of the Advanced Research Weather Research and Forecasting model (ARW-WRF) to simulate changes in BL circulations and summer convection under trade wind conditions, as in Pagowski et al. (2005) and Chiao (2006).
Our primary focus is to analyze the BL confluence over the west coast of Puerto Rico and associated diurnal convection. We seek to characterize BL wind and turbulence profiles in the island wake, where daytime sea breezes play an important role. To achieve our objectives we compare $12-\mathrm{km}$ operational and $1-\mathrm{km}$ simulated WRF model products with observations from a mesonetwork of automatic stations, National Weather Service (NWS) radar, and satellite products. In an effort to improve the observing system, the University of Puerto Rico meteorology program positioned a Scintec Doppler acoustic sounder at Mayaguez airport (MAZ) in 2010 to obtain hourly measurements. In section 2, the data and analysis methods are outlined. Section 3 provides the results, divided into background diurnal cycle, case study observations and model features, and profile intercomparison. Section 4 
provides a concluding discussion. This paper extends the work of J09 through detailed analysis of Doppler acoustic sounder data in conjunction with numerical model wind profiles.

\section{Data and analysis methods}

Mayaguez is located on a bay in the center of the west coast of Puerto Rico (Fig. 1a). Nearby there are a few automatic weather stations, and rain and river gauges maintained by the National Ocean and Atmosphere Administration (NOAA), those reporting via the WunderGround Internet site, and the University of Puerto Rico Mayaguez. Scintec Doppler acoustic sounder measurements were made at Mayaguez airport every hour, consisting of profiles of wind direction, speed, and "sigmaW" at elevations from 40 to $300 \mathrm{~m}$. (Product information on the profiler could be found online at the time of writing at http://www.scintec. com/english/Web/Scintec/Details/A033000.aspx.) The profiler obtained a data capture rate of greater than $75 \%$ during the month of June 2010 from 40 to140 m. There are a number of other routine measurement systems including 12-hourly radiosonde and Aircraft Meteorological Data Relay (AMDAR) aircraft profiles at San Juan, Puerto Rico, and NOAA meteorological buoys in shelf waters. The National Centers for Environmental Prediction (NCEP) assimilate the local and satellite data into various operational and reanalysis products.

Satellite infrared data were analyzed to describe land surface heating and isolated afternoon thunderstorms that develop near Mayaguez. The Climate Prediction Center morphing technique (CMORPH) multisatellite product (Joyce et al. 2004) provides background information on rain rates every $3 \mathrm{~h}$ for a $25-\mathrm{km}$ grid cell over Mayaguez. We study flow patterns and surface heat fluxes around the island using operational WRF model analyses drawn from the NCEP NOAA Operational Model Archive and Distribution System (NOMADS) and NOAA "Ready" Internet sites. A context is provided by averaging certain data for the mean diurnal cycle in June 2010, a midsummer month that has strong solar forcing and prevalent trade winds seldom interrupted by synoptic weather disturbances. In our earlier work (J09) cases were selected when trade winds prevailed, and afternoon island rainfall coincided with clear skies over the surrounding ocean. Here, we have additional insights on the Mayaguez sea breeze from a mesoscale observing system and the Doppler acoustic sounder. Two cases were selected for detailed analysis: 5 and 14 June 2010, and 1-km research WRF model simulations were made as outlined below.

\section{Modeling of case studies}

Numerical simulations are performed using WRFARW, version 3 (detailed information on the WRF model may be found at www.wrf-model.org). Our simulations are configured with an outer domain that encompasses the island of Puerto Rico and about $100 \mathrm{~km}$ of surrounding ocean. A total of 61 unequally spaced layers in the vertical were employed with the lowest model level $10 \mathrm{~m}$ above ground and the uppermost at $50 \mathrm{hPa}$. Two different model forcing data (i.e., initial and time-dependent lateral boundary conditions) were examined, the first using the $12-\mathrm{km}$ operational WRF model assimilated data known as the North American Mesoscale (NAM) product. However, these forcing data resulted in $\sim 30 \%$ overpredicted surface winds. Alternatively, we employed the hindcast $32-\mathrm{km}$ Eta Model product known as the North American Regional Reanalysis (NARR; Mesinger et al. 2006) as the forcing data. Although NARR precipitation is low over the Antilles islands (Jury 2009), the simulations gave realistic kinematic fields and form the basis of our results. Surface temperature fields from Eta data assimilation correspond to collocated station data (from $28.5^{\circ} \mathrm{C}$ offshore to $37^{\circ} \mathrm{C}$ at the warmest leeward point at 1400 LST). Assimilated soil moisture fraction increased from 0.3 on the leeward plains to $>0.6$ on the windward mountains on case days, as compared with station measurements from 0.4 to 0.6 , and a satellite [Advanced Microwave Scanning Radiometer for Earth Observing System (AMSR-E)] June 2010 average of 0.8 .

The model had $18 \mathrm{~h}$ of spinup time prior to convection. The Mellor-Yamada-Janjic (MYJ) BL scheme is employed. In the MYJ scheme (Janjic 2001), the parameterization of turbulence in the $\mathrm{BL}$ represents a nonsingular implementation of the Mellor-Yamada turbulence closure model (Mellor and Yamada 1982) through the full range of atmospheric turbulent regimes. We used the WRF atmospheric radiation scheme of Mlawer et al. (1997), which accounts for longwave and shortwave transfer and interactions between the atmosphere, clouds, and surface. No cumulus parameterization is used; precipitation is produced from grid-scale condensation and convection determined from an explicit moisture scheme that includes ice-phase microphysics (the WRF single-moment 3-class ice scheme). We employed a nested grid with outer and inner domains of $3-\mathrm{km}$ resolution $(160 \times 84$ grid points $)$ and 1 -km resolution $(272 \times 109$ grid points $)$, respectively. The atmospheric component is coupled to a land surface model that includes four soil layers, and solves the water and energy balance equations at the land surface; the 
Noah land surface model is employed with initialization from NARR soil moisture fields in the 0-2-m layer. We make comparative interpretations of operational $12-\mathrm{km}$ model, $1-\mathrm{km}$ model simulation, and observations from the harbor weather station and the airport Doppler acoustic sounder. The processes underlying leeside convection were evaluated from 1-km-resolution WRF fields of low-level winds, equivalent potential temperature, and radar reflectivity fields.

We investigate the spatial structure of prevailing easterly winds across the island, and how these affect BL height (defined by lapse rate and turbulence) and afternoon convection for two summer cases, with a focus on sea breezes on the lee side of Puerto Rico.

\section{Results}

\section{a. Background diurnal cycle and vertical structure}

Midsummer diurnal convection in the Caribbean coincides with a direct solar angle, subsidence from the Hadley cell, and evaporative losses of $>6 \mathrm{~mm} \mathrm{day}^{-1}$ that deplete soil moisture. Figure 1a includes the 100-mlevel wind rose from Doppler acoustic sounder for June 2010, and illustrates the prevailing easterly trade winds with a combined occurrence of $58 \%$. The northwest seabreeze prevalence is $15 \%$ with speeds above $3 \mathrm{~m} \mathrm{~s}^{-1}$ much of the time. The sea breeze is more frequent at $40 \mathrm{~m}(24 \%)$ than at $200 \mathrm{~m}(7 \%)$ during June 2010, suggesting it undercuts the trade winds at times. As the sea breeze is predominantly in the northwest sector, Mayaguez falls within the wind shear regime associated with the northwest corner of the island. The infrared satellite image and surface weather reports in the case of 14 June 2010 illustrate the confluent afternoon circulation and isolated thunderstorm (Fig. 1b). Coastal winds of $>5 \mathrm{~m} \mathrm{~s}^{-1}$ turn $45^{\circ}$ onshore; and the air mass is characterized by $T=31^{\circ} \mathrm{C}$ and $T_{d}=25^{\circ} \mathrm{C}$. Cloud-top temperatures of less than $-60^{\circ} \mathrm{C}$ indicate a convective depth of $13 \mathrm{~km}[175 \mathrm{mb}(\mathrm{hPa})]$ and radius of $\sim 35 \mathrm{~km}$ at 1400 LST. The daytime convergence and orographic lifting by the upslope wind component are likely important for the development of afternoon thunderstorms.

Diurnal averaged rainfall in the Mayaguez area for June 2010 from satellite and the operational Eta product are analyzed in Fig. 2a. The CMORPH satellite estimate shows a mean rise from 1400 to a peak at 1700 LST $\left(3 \mathrm{~mm} \mathrm{~h}^{-1}\right)$ and a gradual decline thereafter. The Eta Model representation has light rainfall in the morning typical of a marine environment, and follows with a terrestrial peak near 1700 LST that is approximately onehalf of the satellite value averaged over June 2010. In earlier work, the Mayaguez sea breeze was found to enhance convection within the prevailing trade wind flow (J09). The mean frequency distribution of June 2010 zonal winds at Mayaguez harbor is analyzed in Fig. 2b. Considering all times of day, weak easterly winds from -1 to $0 \mathrm{~m} \mathrm{~s}^{-1}$ are most prevalent, suggesting the calm island wake overlies the station on average. Focusing on the midday period, it is found that sea breezes from +3 to $+4 \mathrm{~m} \mathrm{~s}^{-1}$ are just as frequent as calm to light trade winds in June 2010. Intercomparison of diurnal air temperature range over the leeward coastal plains reveals morning to afternoon values from $25^{\circ}$ to $31^{\circ} \mathrm{C}$ in station, Eta, and WRF data. Minor differences are attributable to heterogeneous cooling by afternoon showers.

The diurnal cycle of turbulence as measured by the Doppler acoustic sounder at Mayaguez airport $(3 \mathrm{~km}$ inland) is analyzed in Figs. 2c,d for the two cases: 5 and 14 June 2010. There is an alternation between calm nocturnal conditions and midday heating, as expected. SigmaW values of $0.1 \mathrm{~m} \mathrm{~s}^{-1}$ at sunrise jump above $0.8 \mathrm{~m} \mathrm{~s}^{-1}$ by $1100 \mathrm{LST}$ in the BL above $150 \mathrm{~m}$, as solar radiation exceeds $1000 \mathrm{~W} \mathrm{~m}^{-2}$. In the 5 June case, turbulent conditions continue until sunset at MAZ, whereas on 14 June convective rainfall and decreases in shortwave radiation cool the BL (e.g., Fig. 6c), terminating afternoon turbulence by 1500 LST. Diurnal cycling of rainfall is evident in the CMORPH rain rate and Anasco streamflow time series (Fig. 2e), in addition to intermittent synoptic forcing by easterly waves. The streamflow rises on 5 June with a large thunderstorm bringing $\sim 3.9 \times 10^{6} \mathrm{~m}^{3}$ of rain volume to the catchment (Table 1). Another peak in streamflow occurs following the second case of 14 June with $\sim 5.8 \times 10^{6} \mathrm{~m}^{3}$. The synoptic cycling is related to the passage of weak troughs (J09). Diurnal peaks of rainfall, governed by island heating and confluent circulations, are seen on 15 of 20 days in June 2010.

The composite SLP map on sea-breeze days (Fig. 3a) corresponds to an $\sim 1026-\mathrm{mb}$ North Atlantic Ocean anticyclone in midbasin position $\left(\sim 35^{\circ} \mathrm{N}, 30^{\circ} \mathrm{W}\right)$ and lower pressure $(1010 \mathrm{mb})$ north of Panama $\left(10^{\circ} \mathrm{N}\right.$, $80^{\circ} \mathrm{W}$ ) and over the adjacent continents. Trade winds are typically $6 \mathrm{~m} \mathrm{~s}^{-1}$ near Puerto Rico on sea-breeze days with an anticyclone ridge westward toward the Caribbean, but subtropical troughs and African easterly waves are generally weak then. Inspection of upperlevel charts reveals that a ridge lies north of Puerto Rico on the case days.

NWS radiosonde and AMDAR aircraft profiles at San Juan on the northeast coast offer background on the vertical structure. The 0800 LST skew $T$ soundings (Figs. $3 b, c)$ exhibit lapse rates between moist and dry adiabatic 

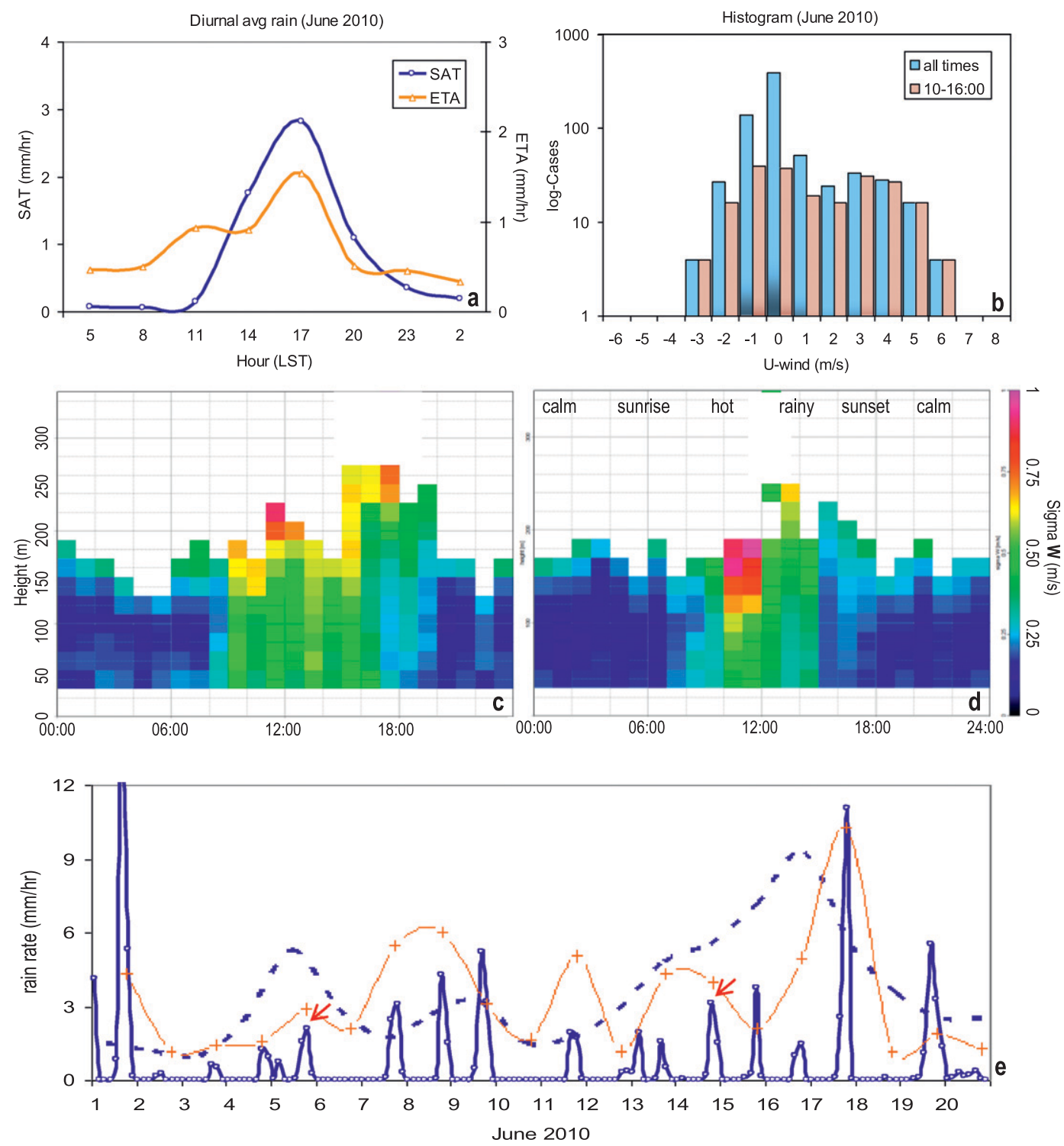

FIG. 2. Background information for Mayaguez: (a) diurnal averaged rain rate from satellite and model assimilation; (b) histogram of hourly zonal winds at harbor station; vertical turbulence measured by acoustic sounder on (c) 5 and (d) 14 Jun 2010; (e) satellite 3-h rainfall (cases are shown with arrows), daily Anasco River discharge (dashed line; $\max =60 \mathrm{~m}^{3} \mathrm{~s}^{-1}$ ), and Mayaguez lightning strikes (orange plus signs; $\max =120 \mathrm{day}^{-1}$ ).

and thus conditionally unstable. Dewpoint depressions are a rather constant $\sim 10^{\circ} \mathrm{C}$ and are largest near $720 \mathrm{mb}$ on 5 June. Winds shift from easterly to westerly above that layer. On 14 June, there was a vertical gradient in dewpoint depression from low values $\left(<5^{\circ} \mathrm{C}\right)$ below $800 \mathrm{mb}$ to $>15^{\circ} \mathrm{C}$ above $700 \mathrm{mb}$, with a stable layer between. Easterly winds prevailed aloft on 14 June. AMDAR profiles are analyzed for 1400 LST (Figs. 3d-f). These

TABLE 1. Contrasts between the two case-study days.

\begin{tabular}{|c|c|c|c|c|c|c|c|c|c|}
\hline 2010 & $\begin{array}{c}\text { CAPE } \\
\text { at } 0800 \mathrm{LST}\end{array}$ & $\begin{array}{l}\text { Upper } \\
\text { winds }\end{array}$ & $\begin{array}{l}\text { Trade } \\
\text { winds }\end{array}$ & $\begin{array}{c}\text { Sea } \\
\text { breeze }\end{array}$ & $\begin{array}{c}\text { Harbor } \\
\text { temperatures* }\end{array}$ & $\begin{array}{l}\text { 11-14-h } \\
\text { Qh flux }\end{array}$ & $\begin{array}{l}14-17-h \\
\text { rain vol }\end{array}$ & $\begin{array}{l}\text { Lightning } \\
\text { strikes }\end{array}$ & $\begin{array}{l}\text { Island } \\
\text { wake }\end{array}$ \\
\hline 5 June & $1860 \mathrm{~J} \mathrm{~kg}^{-1}$ & Westerly & $5 \mathrm{~m} \mathrm{~s}^{-1}$ & $6.5 \mathrm{~h}$ & $\begin{array}{l}28.3^{\circ} \mathrm{C} \mathrm{am} \\
30.5^{\circ} \mathrm{C} \mathrm{pm}\end{array}$ & $150 \mathrm{~W} \mathrm{~m}^{-2}$ & $3.9 \times 10^{6} \mathrm{~m}^{3}$ & 22 & $18.05^{\circ} \mathrm{N}$ south \\
\hline 14 June & $2490 \mathrm{~J} \mathrm{~kg}^{-1}$ & Easterly & $7 \mathrm{~m} \mathrm{~s}^{-1}$ & $3.3 \mathrm{~h}$ & $\begin{array}{l}30.9^{\circ} \mathrm{C} \mathrm{am} \\
25.8^{\circ} \mathrm{C} \mathrm{pm}\end{array}$ & $240 \mathrm{~W} \mathrm{~m}^{-2}$ & $5.8 \times 10^{6} \mathrm{~m}^{3}$ & 37 & $18.25^{\circ} \mathrm{N}$ north \\
\hline
\end{tabular}

\footnotetext{
* Here, am indicates 1000 LST and pm indicates 1600 LST.
} 

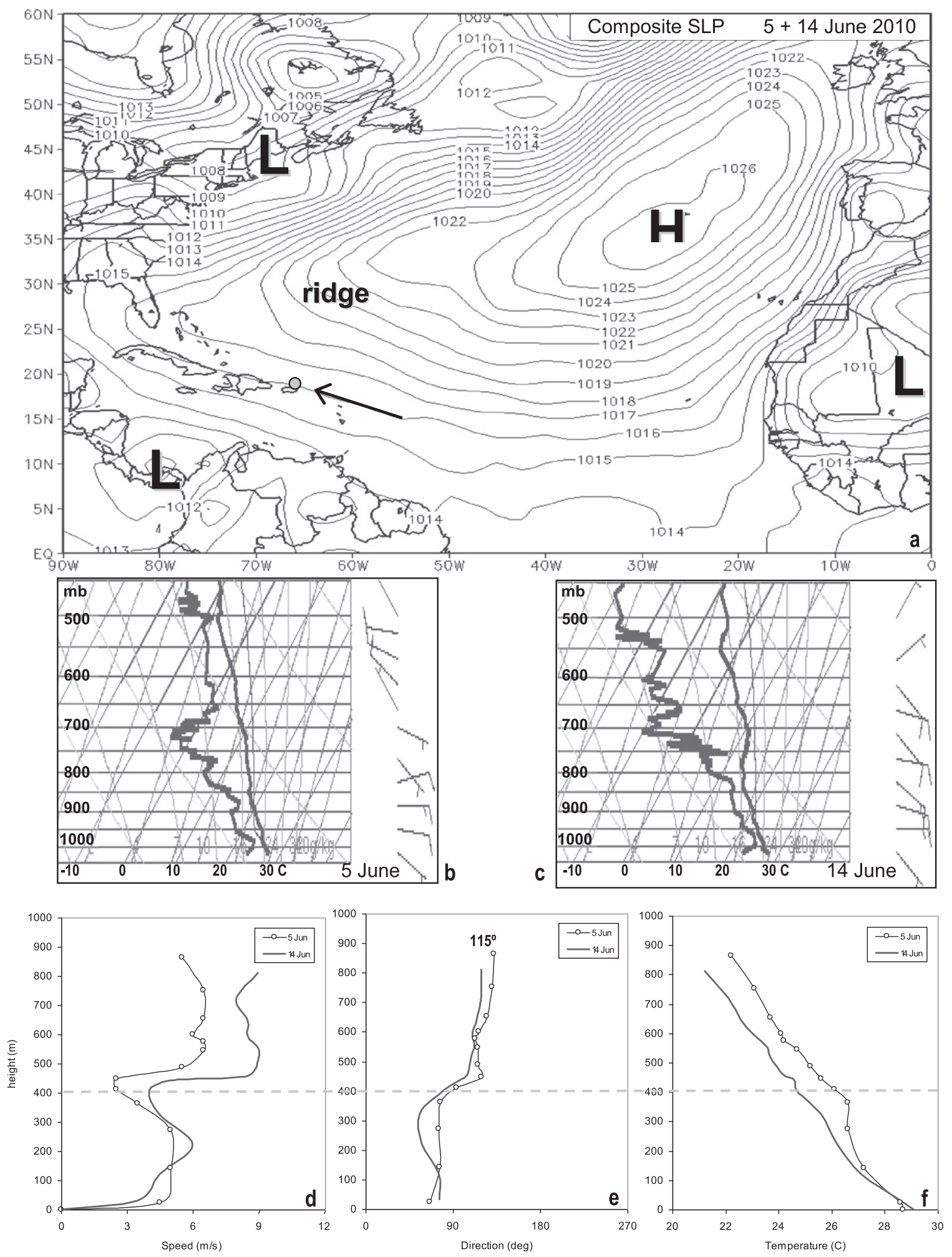

FIG. 3. (a) Composite North Atlantic SLP map for case days. San Juan NWS radiosonde skew T plot at 0800 LST for (b) 5 and (c) 14 Jun 2010. San Juan 1400 LST AMDAR profiles for (d) speed, (e) direction, and (f) temperature with the dashed line being the BL inflow height. 


\section{June}
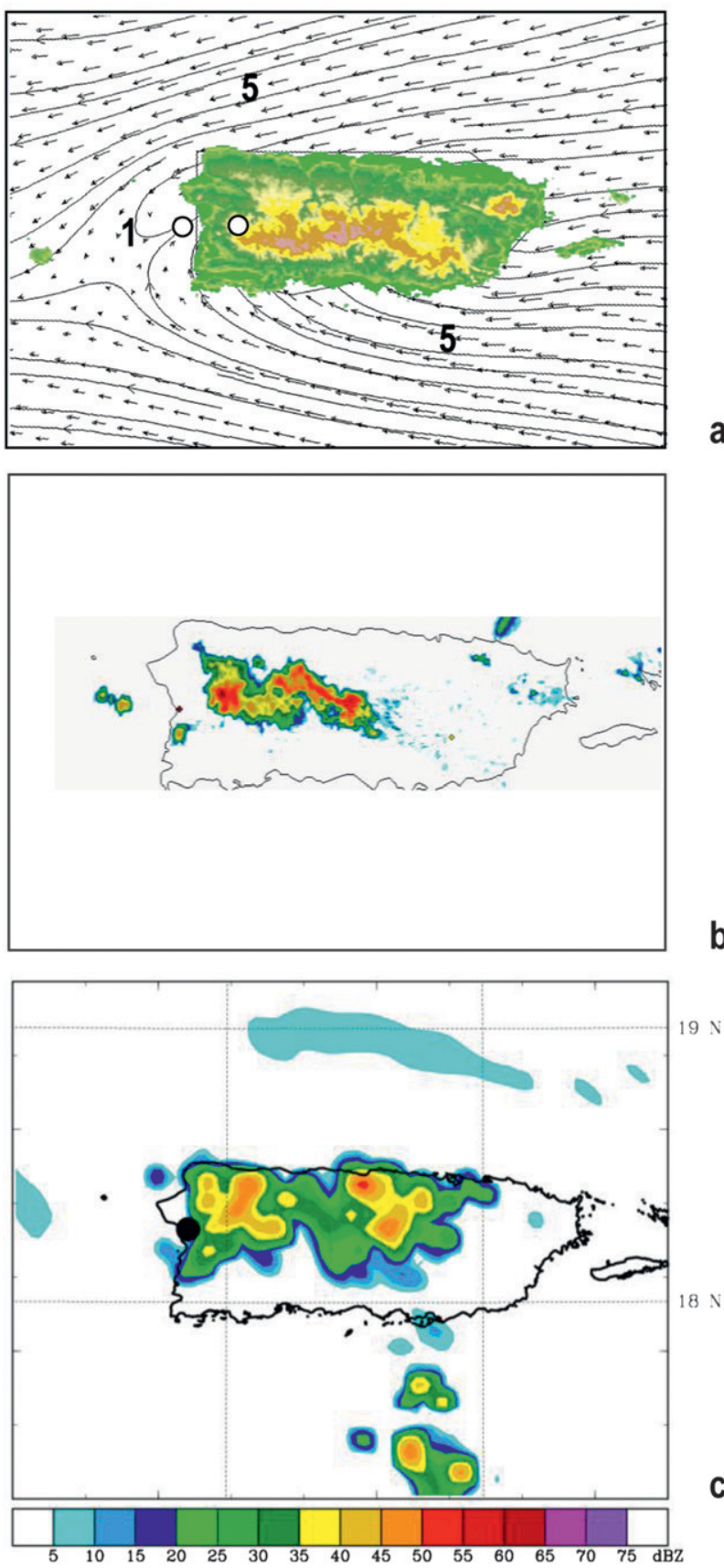

a
14 June 2010
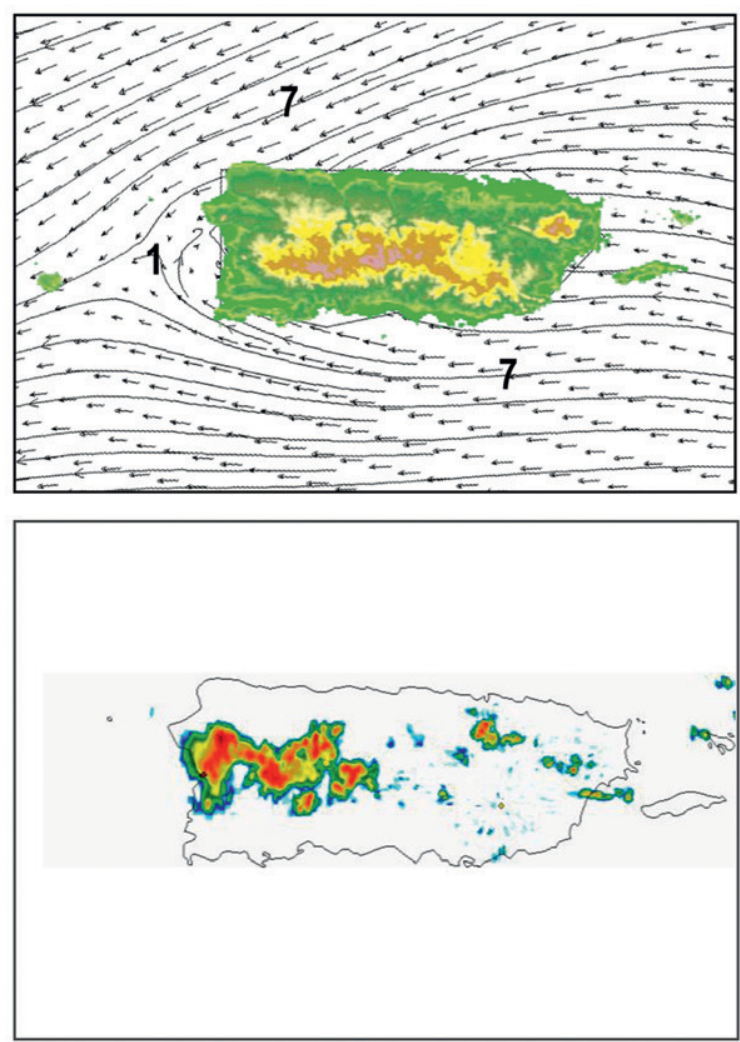

b

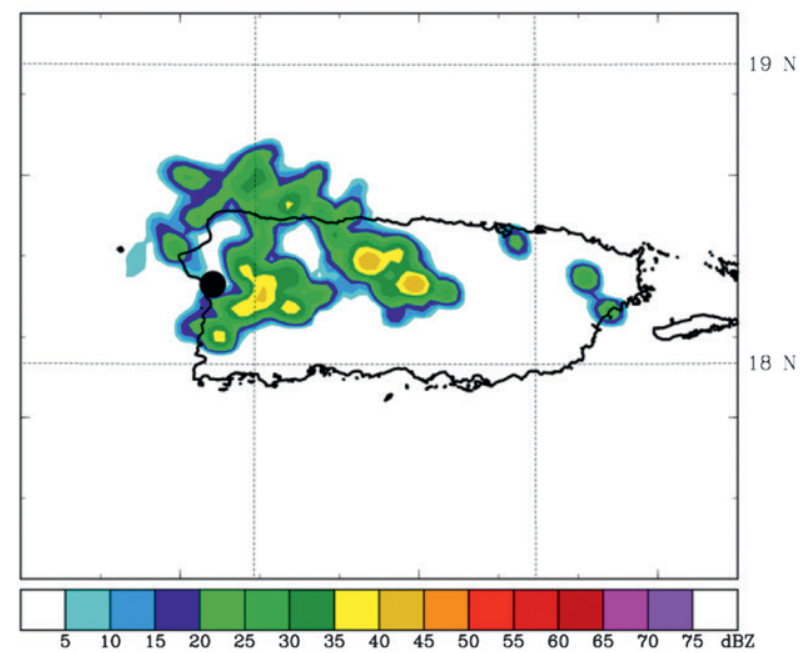

FIG. 4. Operational WRF-model-analyzed (a) 1000-mb marine winds ( $\mathrm{m} \mathrm{s}^{-1}$ ) at 1400 LST for two case days: 5 and 14 Jun 2010 ; (b) 1400 LST NWS radar reflectivity on the same days as (a); (c) 1400 LST 1-km resolution WRF-model-simulated radar reflectivity. Map scales vary.

indicate a 400-m-deep BL layer where island friction and midday heating deflects the trade winds on both days. A weak stable temperature layer (or inversion) is found at $400 \mathrm{~m}$ for the 14 June case, which coincides with a reduction in speed and a change in direction from $70^{\circ}$ in the BL to $115^{\circ}$ aloft.

\section{b. Island-scale features}

The island-scale circulation is studied from operational WRF wind fields. Trade winds of $080^{\circ}$ at $5 \mathrm{~m} \mathrm{~s}^{-1}$ prevailed on 5 June (Fig. 4a), whereas on 14 June directions were $085^{\circ}$ at $7 \mathrm{~m} \mathrm{~s}^{-1}$. Although differences 
seem minor, the Froude number $F=U / N H$ (where $U$ is the wind, $N$ is the Brunt-Väisälä frequency, and $H$ is the mountain height; see J09) is $\sim 0.7$ on 5 June and the island wake is larger. The angle of the trade winds causes the downstream confluence to be in a more southerly position $\left(18.05^{\circ} \mathrm{N}\right)$ on 5 June relative to $14 \mathrm{June}\left(18.25^{\circ} \mathrm{N}\right)$. Convective development over Puerto Rico is analyzed from 1-km WRF-model-simulated radar reflectivity at 1400 LST for the two case days, in comparison with NWS radar reflectivity. On 5 June, the NWS radar indicates a more central axis for convection (Fig. 4b). Reflectivity was slightly higher on 14 June consistent with more intense rainfall (cf. Fig. 1e, Table 1) than 5 June. The WRF simulation for 5 June exhibited more echoes of $>40 \mathrm{~dB} Z$ under weaker trade winds. In both cases, afternoon thunderstorms were simulated to spread over the northwest quadrant of the island, but radar data indicate a narrow east-west-oriented cloud band.

A feature of the confluent circulation around Puerto Rico is the cyclonic-anticyclonic shear zones over the northwest and southwest corners of the island, respectively. The meridional component of the trade winds is analyzed from operational WRF model fields as time-latitude Hovmöller plots over western Puerto Rico (on $67^{\circ} \mathrm{W}$ ) in Fig. 5a. Inward upslope components develop on either side of the island between 1100 and 1700 LST that extend $50 \mathrm{~km}$ north $(-V)$ and south $(+V)$. On 5 June, the two shear zones were more isolated, whereas on 14 June they merged with stronger marine flow. Sensible heat flux Qh maxima coincide with $V$ magnitudes, and reach peak values of $150 \mathrm{~W} \mathrm{~m}^{-2}$ on 5 June and $240 \mathrm{~W} \mathrm{~m}^{-2}$ on 14 June. Flux values here are comparable to those found by Marshall et al. (2004) over Florida. Wind fluctuates as indicated by $+V$ winds near $18^{\circ} \mathrm{N}$ at 1100 and 1700 LST on 14 June. The operational WRF model 3-h time series (Figs. 5b,c) for two points near Mayaguez (cf. Fig. 4a) indicates a peak in surface fluxes at $1100 \mathrm{LST}\left(\mathrm{Qh}=50 \mathrm{~W} \mathrm{~m}^{-2}\right.$ on the bay and $100 \mathrm{~W} \mathrm{~m}^{-2}$ on the mountain; latent heat flux $\mathrm{Qe}=$ $100 \mathrm{~W} \mathrm{~m}^{-2}$ on the bay and $400 \mathrm{~W} \mathrm{~m}^{-2}$ on the mountain), followed by increased zonal wind ( 5 June only) and afternoon rainfall. On 5 June, rain $>5 \mathrm{~mm} \mathrm{~h}^{-1}$ remained inland but was of longer duration (14002000 LST), while on 14 June, rain $>10 \mathrm{~mm} \mathrm{~h}^{-1}$ affected both bay and mountain points in a shorter burst (1400 LST). The operational WRF model at $12-\mathrm{km}$ resolution does not reproduce a sea breeze on 14 June, while on 5 June it affects both bay and mountain points.

\section{c. Observations at Mayaguez}

Sea breezes at the Mayaguez harbor station on 5 and 14 June 2010 (Figs. 6a-d) had varied characteristics (cf. Table 1). Wind directions switched from trade winds $\left(90^{\circ}\right)$ to westerly by 0800 LST on 5 June and from 1000 LST on 14 June. The sea breeze abated later on 5 June (1800) than on 14 June (1400), so total duration was $6.5 \mathrm{~h}$ as compared with $3.3 \mathrm{~h}$. There was an inertial tendency causing wind directions to rotate $30^{\circ}$ from southwest to northwest through midday. On 5 June, convection passed south of the station, interrupting the sea breeze from 1500 to 1600 LST. A large thunderstorm swept through the area on 14 June. Onshore wind speeds increased after 1100 LST with turbulent momentum transfer, and speeds peaked at $5 \mathrm{~m} \mathrm{~s}^{-1}$ around 1400 LST in both cases. Air temperatures were muted by morning clouds on 5 June, eventually reaching an afternoon peak of greater than $30^{\circ} \mathrm{C}$. On the other hand, air temperatures rose steeply on 14 June to a maximum before 1000 LST. As the sea breeze commenced, evaporative cooling over Mayaguez Bay induced a $1.5^{\circ} \mathrm{C}$ drop in air temperature. With 1200 LST coastal air temperatures of $29.8^{\circ} \mathrm{C}$ compared with inland values of $32.1^{\circ} \mathrm{C}$, the sea-to-land gradient is $2.3^{\circ} \mathrm{C}(2.3 \mathrm{~km})^{-1}$. As the afternoon thunderstorm passed by, there was a sudden $5^{\circ} \mathrm{C}$ temperature drop. These fluctuations are supported by shortwave radiation time series at the nearby University station (Fig. 6d). Both days saw the expected Gaussian increase in solar radiation during the morning, with isolated clouds more evident on 5 June. By midday solar radiation spiked above $1000 \mathrm{~W} \mathrm{~m}^{-2}$, but, as convection formed around 1400 LST, values declined sharply on 5 June to $300 \mathrm{~W} \mathrm{~m}^{-2}$ and 14 June to $<100 \mathrm{~W} \mathrm{~m}^{-2}$.

\section{d. Simulation results}

Figure 7 shows the 1-km WRF-model-simulated vertical section and 10-m wind field for 5 June 2010 at 1200 , 1300, and 1400 LST. The model develops a 600-m-deep, $5 \mathrm{~m} \mathrm{~s}^{-1}$ sea breeze that fans out from Mayaguez Bay. The sea breeze penetrates less than $20 \mathrm{~km}$ inland, where it is entrained into convection spreading from the central mountains. The sea-breeze air mass is characterized by $\theta_{e}$ values of $352 \mathrm{~K}$, about $3 \mathrm{~K}$ above ambient. Offshore trade wind flow above the sea breeze is $5 \mathrm{~m} \mathrm{~s}^{-1}$ in the layer $1500-2000 \mathrm{~m}$ and is characterized by $\theta_{e}$ of $332 \mathrm{~K}$, according to the simulation. Changes from midday to afternoon are evident in the deepening of convection that punctuates the kinematic structure via condensation-evaporation and associated weakening of the land-sea temperature gradient. In the $10-\mathrm{m}$ wind field, there is a gradual strengthening of the northern shear zone, so winds in Mayaguez Bay swing from westerly (1200) to northwesterly (1400). As a result, the sea breeze does not penetrate inland, but southward against the southern shear zone. 


\section{June}
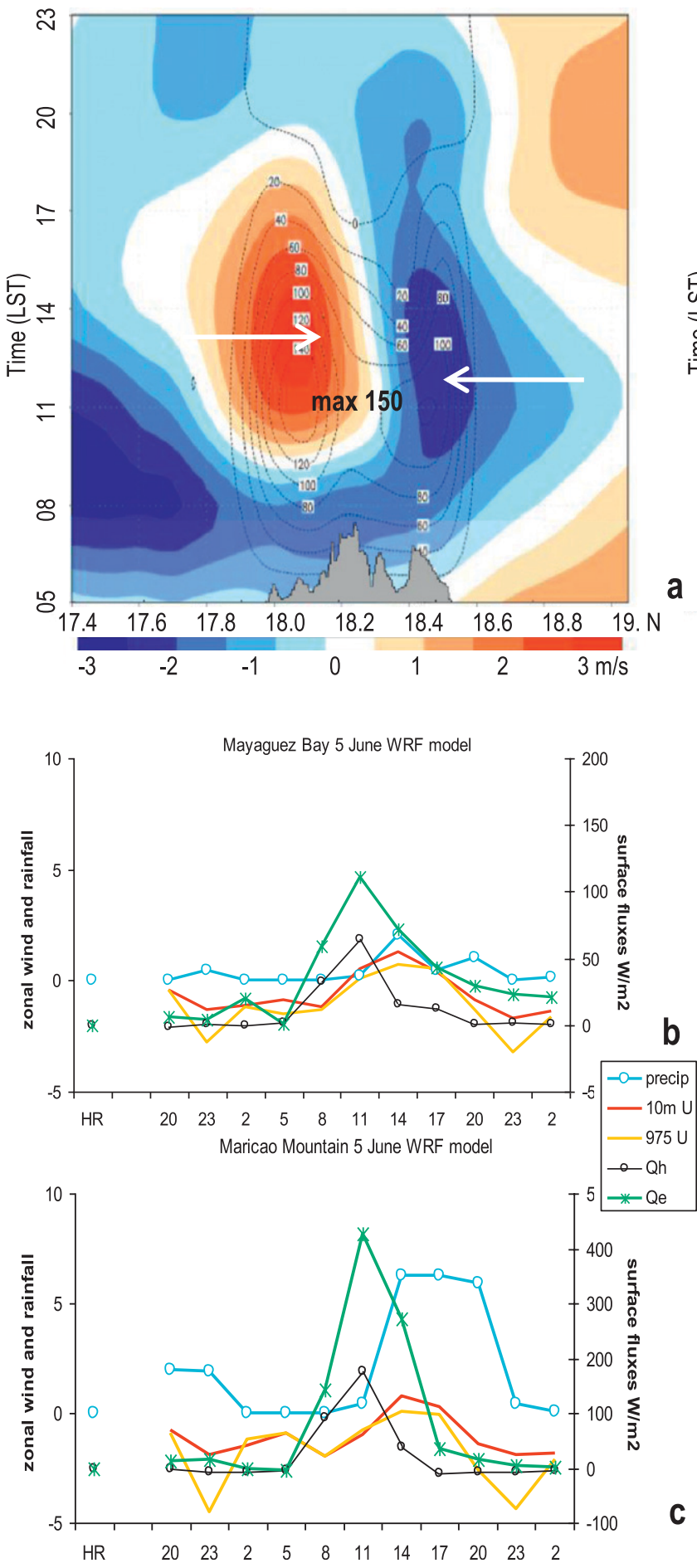

14 June 2010

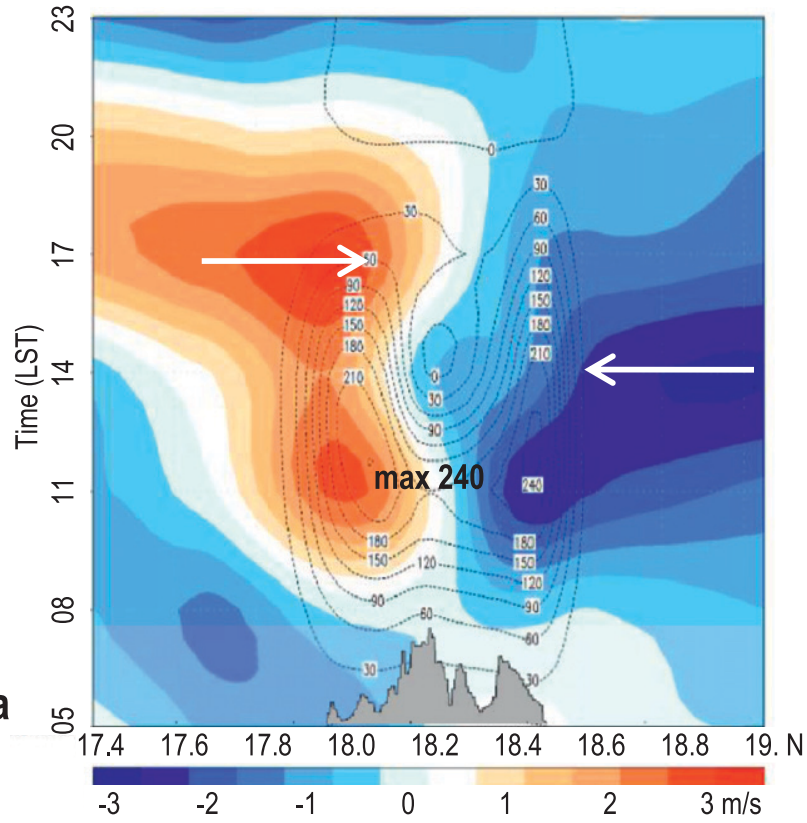

Mayaguez Bay 14 June WRF model
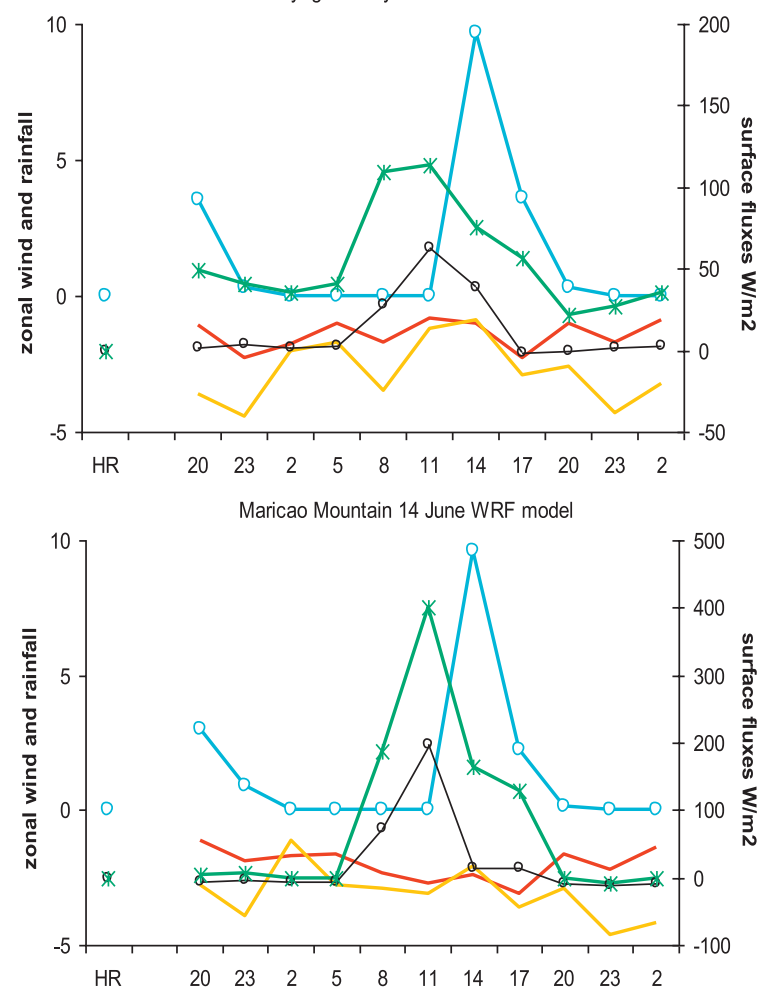

FIG. 5. Operational WRF-model-analyzed (a) $10-\mathrm{m} V$ wind (shaded) and sensible heat flux (contours; W $\mathrm{m}^{-2}$ ) as latitude-time Hovmöller and terrain profile on $67^{\circ} \mathrm{W}$ (dashed in Fig. 1a). Operational WRF-model-analyzed 3-h rain, zonal winds, and surface fluxes at (b) bay and (c) mountain points (cf. Fig. 4a) for (left) 5 and (right) 14 Jun 2010. 

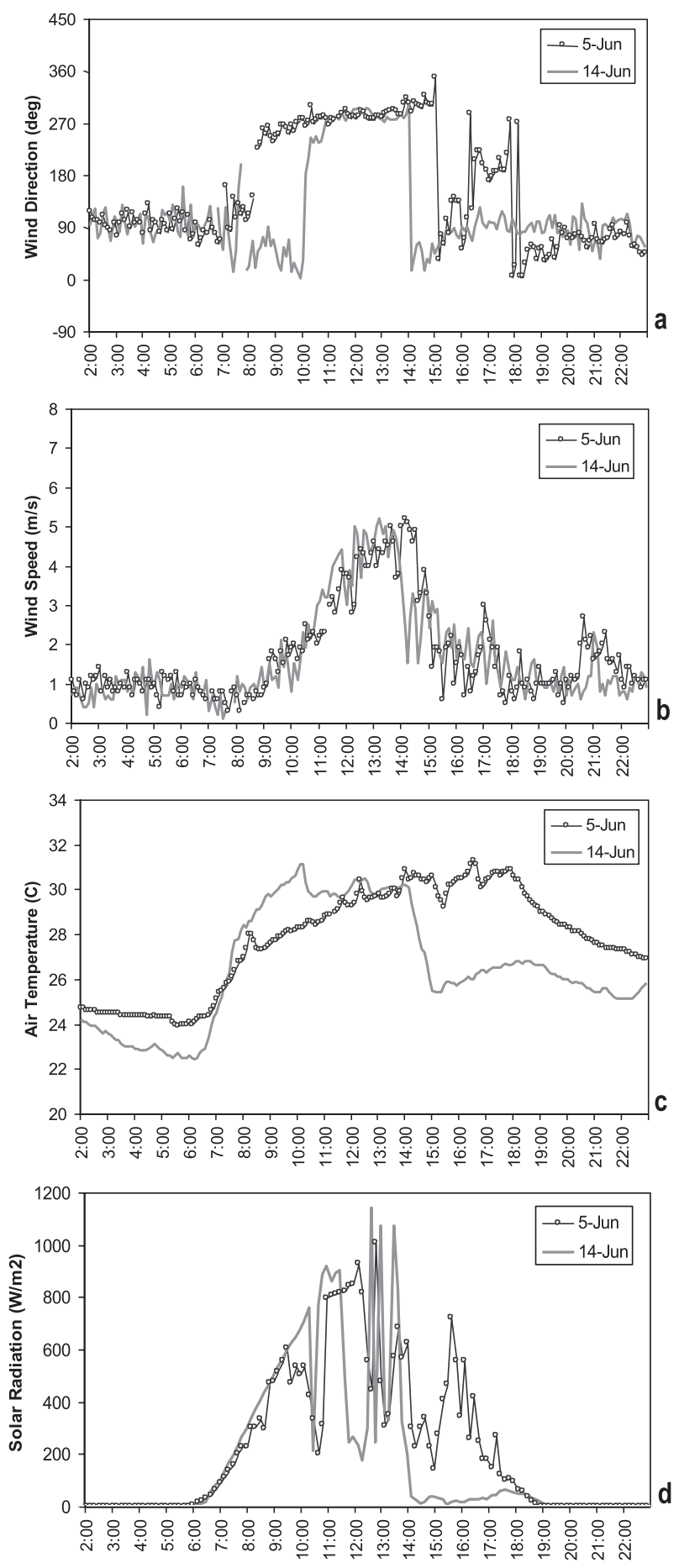

FIG. 6. Time series of 6-min (a) wind direction $\left(^{\circ}\right)$, (b) wind speed $\left(\mathrm{m} \mathrm{s}^{-1}\right)$, and (c) air temperature $\left({ }^{\circ} \mathrm{C}\right)$ at Mayaguez harbor and (d) solar radiation $\left(\mathrm{W} \mathrm{m}^{-2}\right)$ at the university: 5 and 14 Jun 2010. Station positions are given in Fig. $7 \mathrm{~b}$.
In contrast, the 14 June simulated $10-\mathrm{m}$ wind field (Fig. 8) exhibits broad southeasterly flow in the south instead of anticyclonic shear, so confluence is farther north. The sea breeze over Mayaguez Bay has a depth of $700 \mathrm{~m}$ (where $U$ changes sign) and speed of $5 \mathrm{~m} \mathrm{~s}^{-1}$, and penetrates $>20 \mathrm{~km}$ inland where it is drawn into convective elements after 1300 LST. The tendency for the Mayaguez sea breeze to swing to northwesterly is repeated in this case. The offshore trade wind flow above the sea breeze is stronger $\left(8 \mathrm{~m} \mathrm{~s}^{-1}\right)$, deeper $(2-3 \mathrm{~km})$, and drier $\left(\theta_{e}=322 \mathrm{~K}\right)$ in contrast with 5 June. Nevertheless, a noteworthy feature is that in both events some afternoon thunderstorms occur within the island interior over the western part of the island rather than the leeside confluence zone. It appears the thermal forcing from the surface may play an important role.

For wind profiles during the sea breeze at MAZ, the 1-km WRF model indicates a depth of $600 \mathrm{~m}$ where wind speeds decline and wind directions shift from northwest to southeast (Figs. 9a,b). The WRF simulates a maximum of $\sim 5 \mathrm{~m} \mathrm{~s}^{-1}$ near the $100-\mathrm{m}$ level. Intercomparisons with acoustic sounder data (Figs. 9c,d) indicate the sea-breeze strength below $200 \mathrm{~m}$ is overpredicted by $\sim 2 \mathrm{~m} \mathrm{~s}^{-1}$ but directions are close to observed. Acoustic sounder profiles are analyzed to a depth of $300 \mathrm{~m}$ in Figs. 10a,b. Wind speeds show a trend of increasing shear as the sea breeze strengthens to a maximum of $5 \mathrm{~m} \mathrm{~s}^{-1}$ at 1400 LST in both cases. The directional profiles identify the longer duration of the sea breeze on 5 June $(6 \mathrm{~h})$ than on 14 June $(3 \mathrm{~h})$. Model-simulated wind shear in the 40 200 -m layer was too weak $\left(0.5 \times 10^{-2} \mathrm{~s}^{-1}\right)$ in comparison with acoustic sounder data $\left(2 \times 10^{-2} \mathrm{~s}^{-1}\right)$.

\section{Concluding discussion}

The midsummer BL circulation and afternoon thunderstorm convection over Mayaguez were studied using observations and high-resolution models. Patterns of BL temperature and confluence were evaluated as triggers for thunderstorms that form in the island wake, as in Nordeen et al. (2001). Satellite infrared data were used to identify cases on 5 and 14 June 2010 when 1100 LST surface temperatures show a $2^{\circ}-3^{\circ} \mathrm{C}$ increase from coast to inland and 1500 LST cloud-top temperatures reach $-60^{\circ} \mathrm{C}$. Considering a simplified equation for scale analysis of the sea breeze: $\Delta U=[(g H / \theta) d \theta / d x] d t$ (Pielke and Segal 1986), where $d t=7.2 \times 10^{3} \mathrm{~s}$ is the time interval from calm to peak sea breeze, $g$ is gravity, $H$ is representative depth for the temperature gradient, $\theta$ is $1000-\mathrm{mb}$ temperature ( $304 \mathrm{~K})$, and $d \theta / d x$ is the observed 1200 LST land-sea air temperature gradient $+2^{\circ} \mathrm{C}(3 \mathrm{~km})^{-1}$. Assuming $H \sim 20 \mathrm{~m}$, a $\Delta U$ of $5 \mathrm{~m} \mathrm{~s}^{-1}$ is obtained at $1400 \mathrm{LST}$, consistent with 
5 June 2010
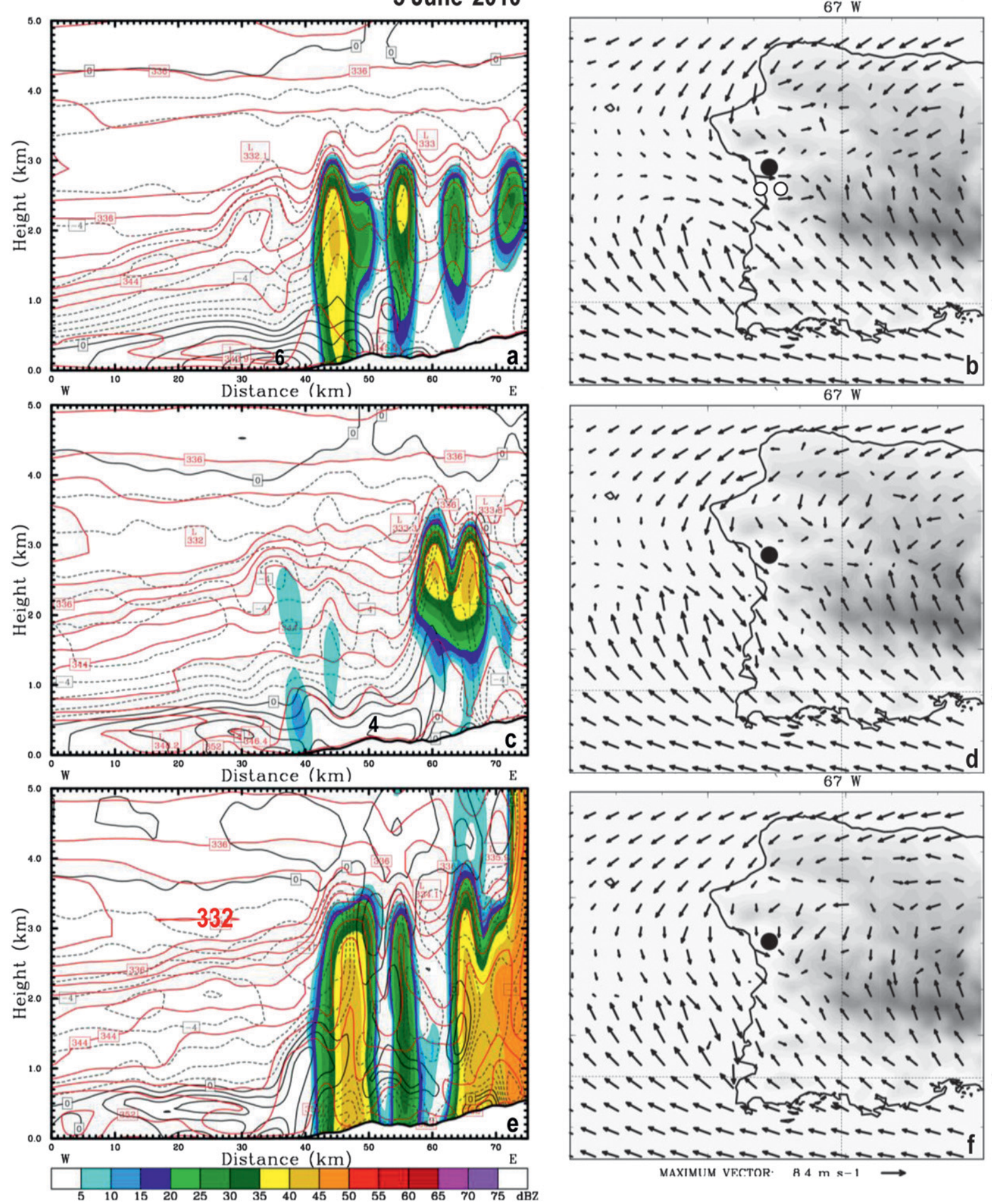

FIG. 7. The 1-km-resolution WRF-model-simulated vertical east-west section on MAZ [black dot in (b),(d),(f)] of zonal wind (black lines), equivalent potential temperature (red lines), and radar reflectivity (shaded) for (a) 1200, (c) 1300, and (e) 1400 LST 5 Jun 2010. (b),(d),(f) The 10-m wind field for same times as in (a),(c),(e). Harbor and university stations are open dots in (b). 
14 June 2010
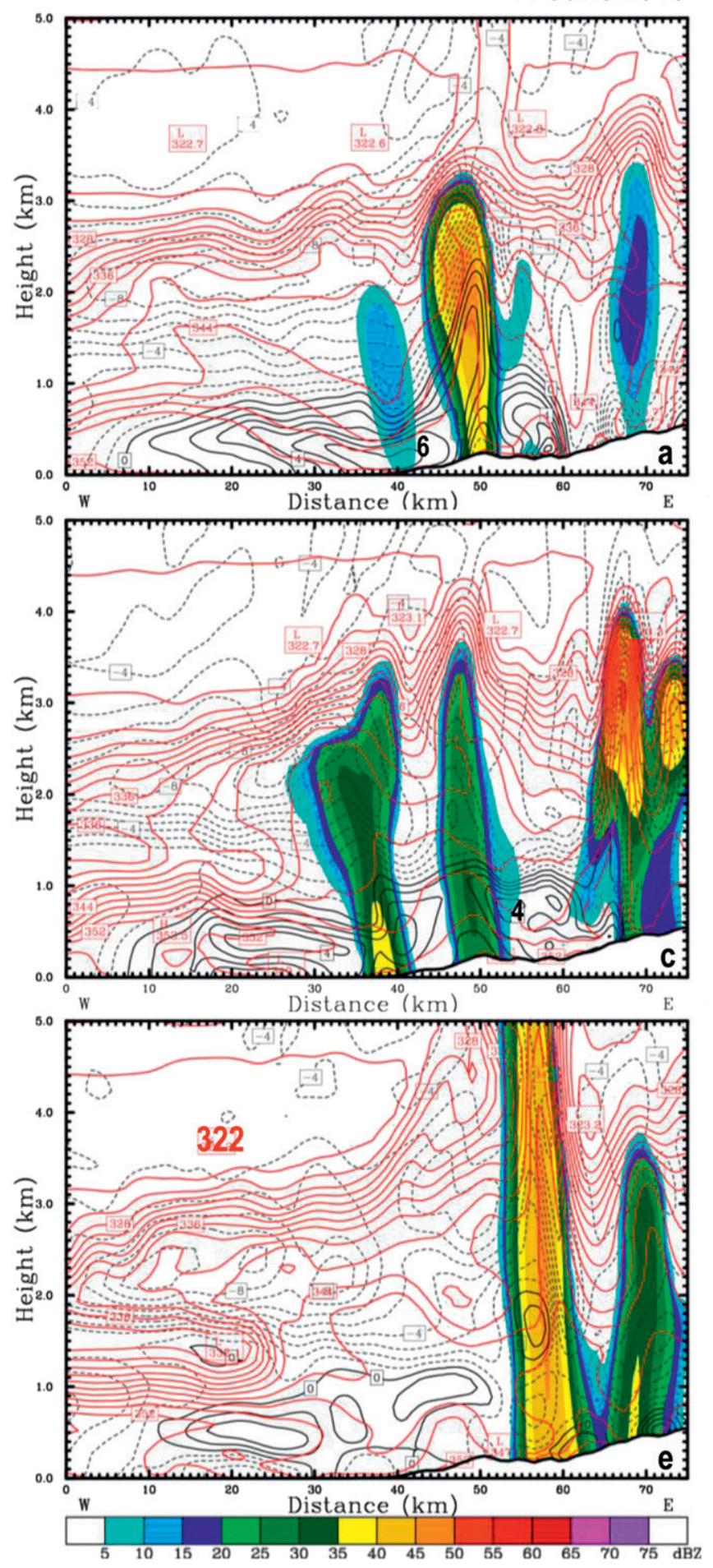

$67 \mathrm{~W}$

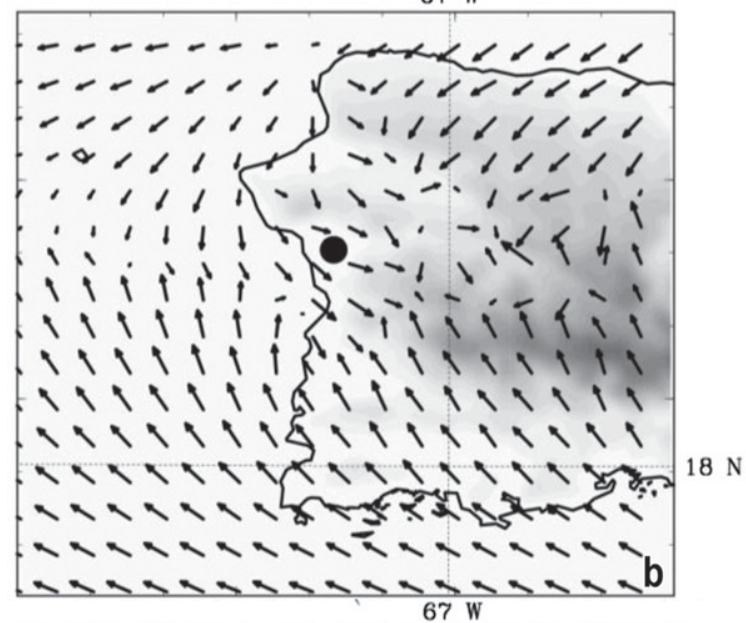

- - - 1 +

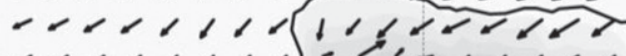

$-1,1+1)$

$101,1+1,1+2+2$

$\therefore 1+1 \Lambda_{1}+11-\infty+1$

$\therefore \therefore 11+701100$

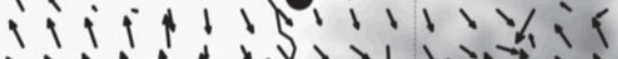

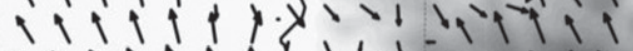

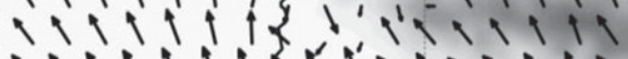

11111916211121111

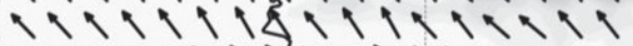

$1111018 \mathrm{~N}$

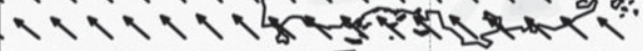

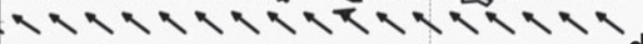

ararararararad $67 \mathrm{~W}$

- - - - -

-

-

$-1, \alpha<1,1,111$,

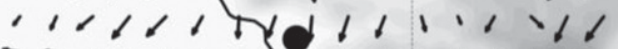

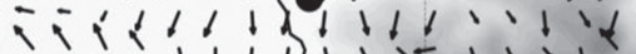

$111+1+1+1+12-11210$

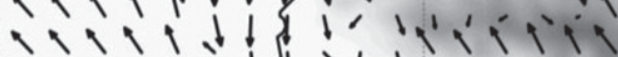

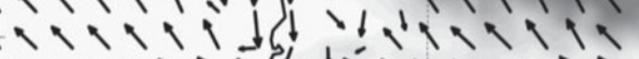

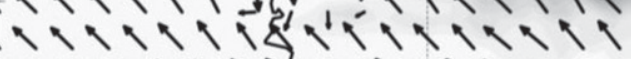

$111018 \mathrm{~N}$

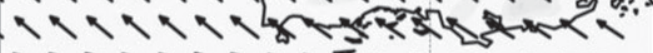

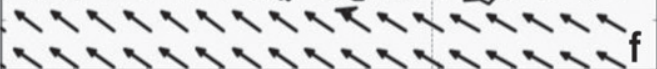

MAXimUim VFCTOR. 8 9 $\mathrm{m} \mathrm{s}-1 \rightarrow$

FIG. 8. As in Fig. 7, but for 14 Jun 2010.

observations and simulations shown here. Differences were found between the two cases: there was a shorter sea breeze on 14 June because of stronger winds and convection, with lower shortwave radiation (cf. Fig. 6d).
Acoustic sounder profiles were obtained to study diurnal winds and turbulence in the 40-200-m layer. Simulated wind shear is weak $\left(0.5 \times 10^{-2} \mathrm{~s}^{-1}\right)$ in comparison with acoustic sounder data $\left(2 \times 10^{-2} \mathrm{~s}^{-1}\right)$. 

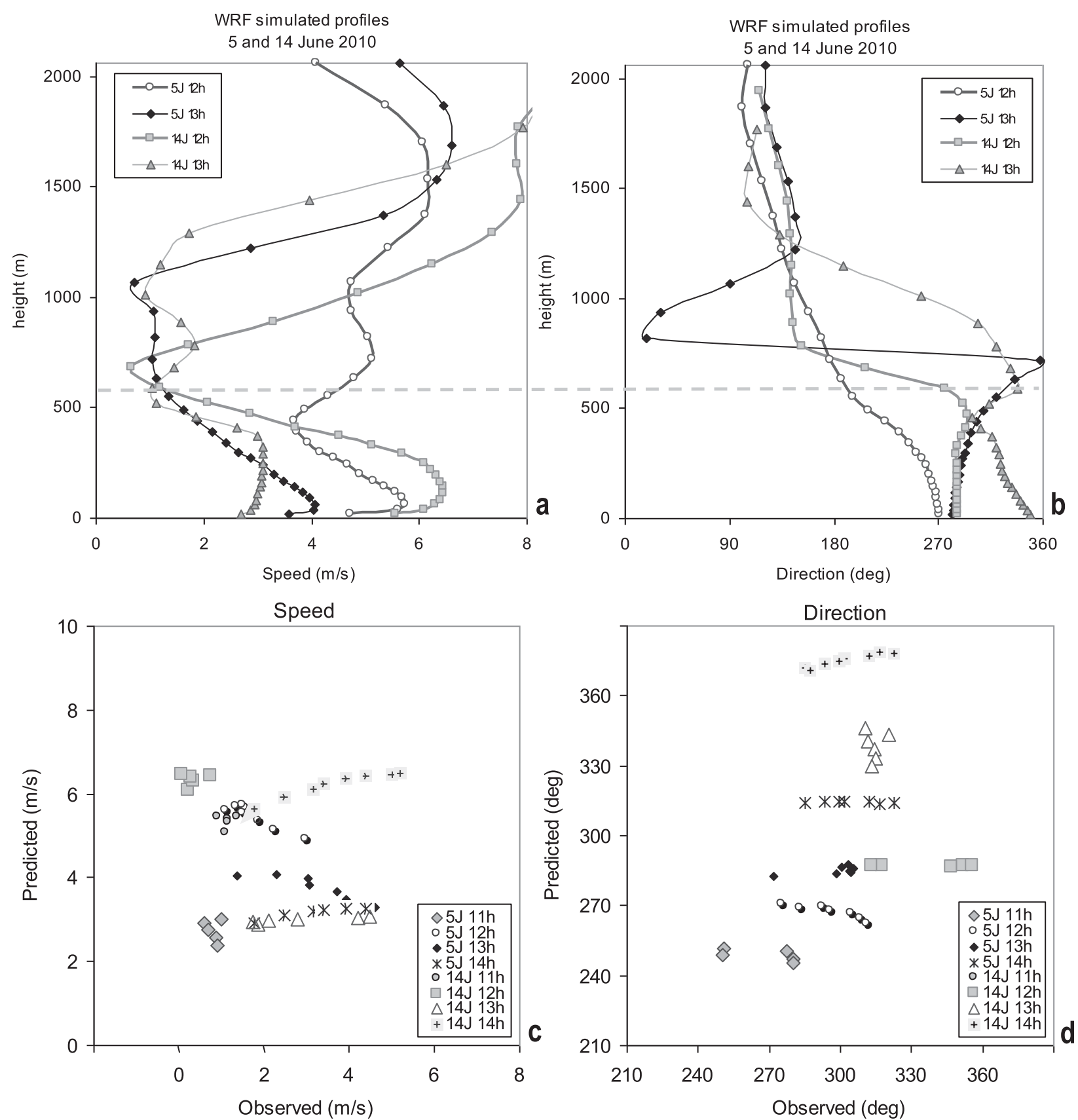

FIG. 9. The 1-km WRF-simulated (a) wind speed and (b) direction profiles at MAZ for 1200 and 1300 LST 5 and 14 Jun 2010 with sea-breeze depth dashed. (c) Speed and (d) direction intercomparison with acoustic sounder data for levels 40-200 m in the hours 1100-1400 LST.

Perhaps surface friction is underestimated in the WRF input fields. In the operational $12-\mathrm{km}$ WRF model, $z_{0}=0.36 \mathrm{~m}$ in the grid cell of Mayaguez airport. Using the $\log$-wind profile $U_{z}=U^{*} / k\left(\ln z / z_{0}\right)$ with friction velocity $U^{*}=0.2 \mathrm{~m} \mathrm{~s}^{-1}$, we obtain wind shear consistent with our simulation that is much less than observed. Employing the Ekman wind solution $U_{z}=\mathrm{Ug}\left[1-e^{-a z} \cos (a z)\right]$ where $\mathrm{Ug}$ is geostrophic wind, $a=(f / 2 \mathrm{~K})^{0.5}, f$ is the Coriolis parameter, and $K$ is the eddy viscosity $=5 \mathrm{~m}^{2} \mathrm{~s}^{-1}$ for turbulent flow over rough terrain, we obtain a wind shear close to observed. This suggests the need to conduct further WRF simulations with varying surface roughness. 

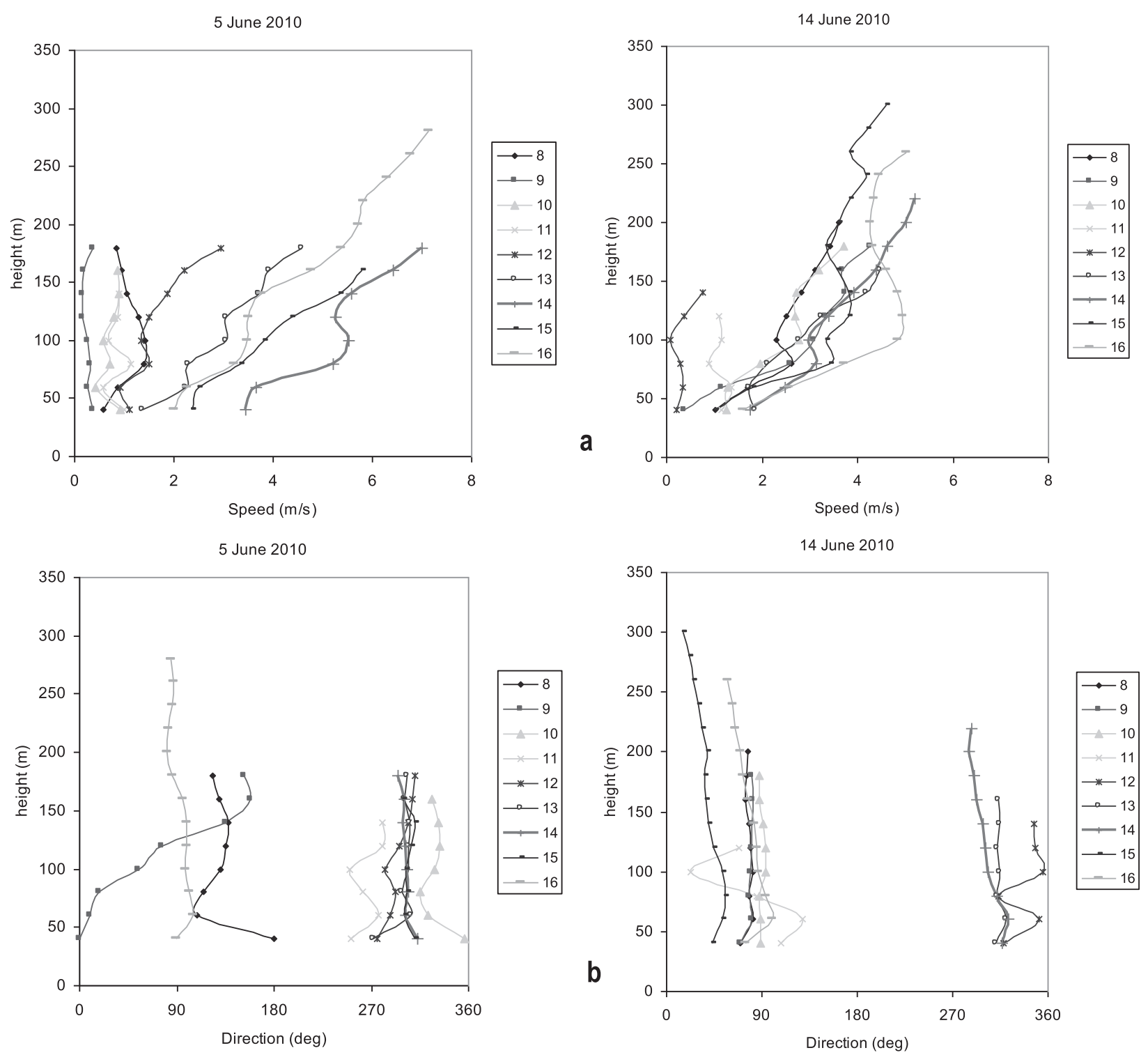

FIG. 10. Acoustic sounder measured (a) wind speed and (b) direction profiles at MAZ for daytime hours on (left) 5 and (right) 14 Jun 2010.

One-kilometer WRF simulations exhibit sea-breeze entrainment in convective cells near Mayaguez, yet cumulative rain volume was similar to the operational 12-km NAM analyses. A clear advantage of the finer resolution is an improved representation of confluent circulations and convection between northern and southern shear zones. In our 1-km simulation CAPE values were $20 \%$ overpredicted so model rainfall started too early (1300 LST) and convection spread too far north [Aguadilla (BQN)] under southeasterly 900-700-mb winds. We found that simulated 900-mb winds upstream at San Juan International Airport (SJU) remained easterly on 14 June, but on $5 \mathrm{June}$, the wind shift was from $100^{\circ}$ to $160^{\circ}$ over the 18-h model run. With the simulated flow out of alignment with the island, winds over the northwest corner weakened and could not "contain" the convection near Mayaguez. Hence, the evolving atmospheric state in the NARR initialization data misled the simulation. In reality, the Atlantic Ridge and associated trade winds persisted. Another issue is the exclusion of the downstream island of Hispaniola from the nested model domain, which may leave zonal flows less constrained.

The land surface modeling and assimilation of precipitation and satellite radiance profiles in the hindcast NARR fields provided better representation of boundary conditions around Puerto Rico than the operational 
NAM fields, possibly because the latter is located at the corner of its domain. Moreover, the sea-breeze overestimate was $1-2 \mathrm{~m} \mathrm{~s}^{-1}$ with the NARR initialization while the trade winds were adequately captured. The wind bias would have been greater with NAM forcing data. It appears the dry bias using the NARR initialization on the leeside plain in the $1-\mathrm{km}$ domain would result in stronger surface heating. Thus, the sea-breeze strength below $200 \mathrm{~m}$ is overpredicted. Subsequently, afternoon thunderstorms that occurred within the island interior may have been caused by the stronger surface heating. Thus, the initial soil moisture needs to be improved. Further uncertainty also derives from the WRF model SST, BL parameterization, and cloud microphysics. To overcome any bias from NARR initialization, further simulations could make use of the climate forecast system reanalysis product (Saha et al. 2010). Sensitivity tests and quantitative validations using various parameterization schemes will be the focus of future research.

Acknowledgments. We acknowledge the suppliers of datasets employed here. The UPRM acoustic sounder was supported by NSF EPSCOR. The critical reviews of three anonymous reviewers were very helpful. This research was partly supported by the Grant W911NF-09-10441 from the U.S. Army Research Office.

\section{REFERENCES}

Bennett, S. P., V. Grubišić, and R. M. Rasmussen, 1998: Gravity waves, rainbands, and deep convection induced by trade wind flow over Puerto Rico. Preprints, 12th Conf. on Numerical Weather Prediction, Phoenix, AZ, Amer. Meteor. Soc., 98102.

Blanchard, D. O., and R. E. López, 1985: Spatial patterns of convection in south Florida. Mon. Wea. Rev., 113, 1282-1299.

Burk, S. D., T. Haack, L. T. Rogers, and L. J. Wagner, 2003: Island wake dynamics and wake influence on the evaporation duct and radar propagation. J. Appl. Meteor., 42, 349367.

Carbone, R. E., J. W. Wilson, T. D. Keenan, and J. M. Hacker, 2000: Tropical island convection in the absence of significant topography. Part I: Life cycle of diurnally forced convection. Mon. Wea. Rev., 128, 3459-3480.

Carlis, D. L., Y.-L. Chen, and V. Morris, 2010: Numerical simulations of island-scale airflow and the Maui vortex during summer trade-wind conditions. Mon. Wea. Rev., 138, 27062736.

Chiao, S., 2006: Performance of planetary boundary layer schemes in the WRF model. Proc. 25th Army Science Conf., Orlando, FL, ASAALT, OP-03.

Cooper, H., M. Garstang, and J. Simpson, 1982: The diurnal interaction between convection and peninsular-scale forcing over south Florida. Mon. Wea. Rev., 110, 486-503.

Etling, D., 1989: On atmospheric vortex streets in the wake of large islands. Meteor. Atmos. Phys., 41, 157-164.
Grubišić, V., R. B. Smith, and C. Schär, 1995: The effect of bottom friction on shallow-water flow past an isolated obstacle. J. Atmos. Sci., 52, 1985-2005.

Janjic, I. Z., 2001: Nonsingular implementation of the MellorYamada level 2.5 scheme in the NCEP Meso Model. NCEP Office Note 437, 61 pp.

Joyce, R. J., J. E. Janowiak, P. A. Arkin, and P. Xie, 2004: CMORPH: A method that produces global precipitation estimates from passive microwave and infrared data at high spatial and temporal resolution. J. Hydrometeor., 5, 487-503.

Jury, M. R., 2009: An inter-comparison of observational, reanalysis, satellite, and coupled model data on mean rainfall in the Caribbean. J. Hydrometeor., 10, 413-430.

- S. Chiao, and E. W. Harmsen, 2009: Mesoscale structure of trade wind convection over Puerto Rico, composite observations and numerical model simulation. Bound.-Layer Meteor., 132, 289-313.

Keenan, T. D., and Coauthors, 2000: The Maritime Continent Thunderstorm Experiment: Overview and results. Bull. Amer. Meteor. Soc., 81, 2433-2455.

Kingsmill, D. E., 1995: Convection initiation associated with a seabreeze front, a gust front, and their collision. Mon. Wea. Rev., 123, 2913-2933.

Liu, C., and M. W. Moncrieff, 1996: A numerical study of the effects of ambient flow and shear on density currents. Mon. Wea. Rev., 124, 2282-2303.

Malkus, J. S., 1955: The effects of a large island upon the tradewind air stream. Quart. J. Roy. Meteor. Soc., 81, 538-550.

Marshall, C. H., R. A. Pielke, L. T. Steyaert, and D. A. Willard, 2004: The impact of anthropogenic land-cover change on the Florida peninsula sea breezes and warm season sensible weather. Mon. Wea. Rev., 132, 28-52.

Mellor, G. L., and T. Yamada, 1982: Development of a turbulence closure model for geophysical fluid problems. Rev. Geophys., 20, 851-875.

Mesinger, F., and Coauthors, 2006: North American Regional Reanalysis. Bull. Amer. Meteor. Soc., 87, 343-360.

Mlawer, E. J., S. J. Taubman, P. D. Brown, and M. J. Iacono, 1997: Radiative transfer for inhomogeneous atmospheres: RRTM, a validated correlated- $k$ model for the longwave. J. Geophys. Res., 102, 16 663-16 682.

Nguyen, H. V., Y.-L. Chen, and F. Fujioka, 2010: Numerical simulations of island effects on airflow and weather during the summer over the island of Oahu. Mon. Wea. Rev., 138, 2253-2280.

Nordeen, M. L., P. Minnis, D. R. Doelling, D. Pethick, and L. Nguyen, 2001: Satellite observations of cloud plumes generated by Nauru. Geophys. Res. Lett., 28, 631-634.

Pagowski, M., J. Hacker, and J.-W. Bao, 2005: Behavior of WRF PBL schemes and land-surface models in 1-D simulations during BAMEX. Preprints, WRF Users Workshop, Boulder, CO, NCAR, 27-30.

Pearce, R. P., R. C. Smith, and J. S. Malkus, 1956: The calculation of a sea-breeze circulation in terms of the differential heating across the coast line. Quart. J. Roy. Meteor. Soc., 82, 235-241.

Pielke, R. A., and M. Segal, 1986: Mesoscale circulations forced by differential terrain heating. Mesoscale Meteorology and Forecasting, P. S. Ray, Ed., Amer. Meteor. Soc., 516-548.

Rasmussen, R. M., P. K. Smolarkiewicz, and J. Warner, 1989: On the dynamics of Hawaiian cloud bands: Comparison of model results with observations and island climatology. J. Atmos. Sci., 46, 1589-1608.

Saha, S., and Coauthors, 2010: The NCEP Climate Forecast System Reanalysis. Bull. Amer. Meteor. Soc., 91, 1015-1057. 
Schar, C., and R. B. Smith, 1993a: Shallow-water flow past isolated topography. Part I: Vorticity production and wake formation. J. Atmos. Sci., 50, 1373-1400.

$\longrightarrow$, and 1993b: Shallow-water flow past isolated topography. Part II: Transition to vortex shedding. J. Atmos. Sci., 50, 1401-1412.

Smith, R. B., and V. Grubišić, 1993: Aerial observations of Hawaii's wake. J. Atmos. Sci., 50, 3728-3750.

— A. C. Gleason, P. A. Gluhosky, and V. Grubišić, 1997: The wake of St. Vincent. J. Atmos. Sci., 54, 606-623.
Smolarkiewicz, P. K., R. M. Rasmussen, and T. L. Clark, 1988: On the dynamics of Hawaiian cloud bands: Island forcing. J. Atmos. Sci., 45, 1872-1905.

Wakimoto, R. M., and N. T. Atkins, 1994: Observations of the seabreeze front during CaPE. Part I: Single-Doppler, satellite, and cloud photogrammetry analysis. Mon. Wea. Rev., 122, 1092-1114.

Wilson, J. W., and W. E. Schreiber, 1986: Initiation of convective storms at radar-observed boundary-layer convergence lines. Mon. Wea. Rev., 114, 2516-2536. 
Copyright of Journal of Applied Meteorology \& Climatology is the property of American Meteorological Society and its content may not be copied or emailed to multiple sites or posted to a listserv without the copyright holder's express written permission. However, users may print, download, or email articles for individual use. 